\title{
Increase of Energy Potential of Russian Forest resources due to Climate Change and $\mathrm{CO}_{2}$ Fertilization
}

\author{
Vladimir Klimenko ${ }^{1, *}$, Alexei Tereshin ${ }^{1}$, and Olga Mikushina ${ }^{1}$ \\ ${ }^{1}$ National Research University “MPEI”, 111250 Krasnokazarmennaya St., 14, Moscow, Russia
}

\begin{abstract}
Biofuels are an important energy source, currently providing about $10 \%$ of the world energy demand, including $2 \%$ of global electricity generation and the same share of total liquid fuel consumption. Wood fuel in Russia is one of the most affordable and most important type of renewable energy resources. In this paper we study the possible changes in energy potential of Russia's forest resources as a result of changes in the atmosphere and climate. The estimates of the global dioxide concentrations dynamics and mean annual air temperature change over the Russian territory for the period up to 2050 are developed using the MPEI models of the carbon cycle and regional climate. The calculations show that the change of net primary productivity of forests of Russia as a result of the $\mathrm{CO}_{2}$ abundance increase in the atmosphere, as well as of the increase of the air temperature and rainfall will enhance available energy resources of wood fuel by mid-century by more than 9 million tons of coal equivalent (Mtce).
\end{abstract}

\section{Introduction}

Biofuels are an important source of energy, currently providing about $10 \%$ of the world's total energy demand, and it is almost the same share that of hydro and nuclear power combined. Basically it is a type of so-called noncommercial resources - firewood and agricultural wastes used as fuel in rural households. However, recently, the amount of commercial use of bioenergy for heat and power generation increased (to more than $2 \%$ of the total world electricity generation in 2017), as well as a motor fuel (to almost $2 \%$ of the world liquid fuels consumption in 2017). In the past fifteen years, the growth rate of energy production from biomass (about $6 \%$ per year) was nearly five times higher than the average growth rate of energy consumption in the world.

Biofuels in Russia currently are the basis of renewable energy sources: in $2015,90 \%$ of renewable centralized heat and electricity was produced from fuel wood, agricultural residues and biogas with the contribution of the latter two fairly negligible (Table 1). Recalculation of heat and electricity into the primary energy was made using the average specific fuel consumption in Russia for thermal power plants $(0.326$ tce/MWh) and boilers ( 0.166 tce/Gcal) respectively. The share of biofuel-based thermal power plants in Russia is slightly higher than the world average, and amounts to 2$3 \%$ of the total national electricity generation. In some regions with the developed forest industry (mostly in North-West of Russia) this share reaches 5-10\%.

The amount of fuelwood used by the households for heating, cooking and other domestic needs (noncommercial biofuel) in the last decades is rather stable and comprise 4-5 Mtce annually - about a half of total biofuel consumption.

Table 1. Renewable energy consumption in Russia (Mtce)

\begin{tabular}{|c|c|c|c|c|}
\hline Energy source & 2000 & 2005 & 2010 & 2015 \\
\hline $\begin{array}{l}\text { Hydro } \\
\text { (excluding large } \\
\text { HPP) }\end{array}$ & 0.227 & 0.242 & 0.261 & 0.267 \\
\hline Solar & 0.000 & 0.000 & 0.009 & 0.105 \\
\hline Wind & 0.001 & 0.002 & 0.001 & 0.047 \\
\hline Geothermal & 0.018 & 0.131 & 0.158 & 0.148 \\
\hline $\begin{array}{l}\text { Commercial } \\
\text { biofuels }\end{array}$ & 4.000 & 4.328 & 5.001 & 5.246 \\
\hline TOTAL & 4.246 & 4.703 & 5.429 & 5.813 \\
\hline $\begin{array}{l}\text { including } \\
\quad \text { wood fuel }\end{array}$ & 3.929 & 4.248 & 4.860 & 5.099 \\
\hline $\begin{array}{r}\text { agricultural } \\
\text { waste }\end{array}$ & 0.036 & 0.036 & 0.084 & 0.071 \\
\hline biogas & 0.035 & 0.044 & 0.057 & 0.075 \\
\hline Fuelwood & 4.647 & 5.011 & 4.195 & 4.100 \\
\hline Total biofuel & 8.647 & 9.339 & 9.196 & 9.346 \\
\hline Including wood & 8.576 & 9.259 & 9.055 & 9.099 \\
\hline
\end{tabular}

Biofuels, like other renewables, are the modern alternative to fossil fuel, safe from the standpoint of human impact on the atmosphere and climate. A handful of research papers studied the various aspects of the biological resources use in the energy sector [1-2], assessing their impact on the global carbon cycle and the thermal balance of the atmosphere [3-4], explored the impact of climate change on forest ecosystems [3, 5]. The objectives of the present work is evaluation of the

Corresponding author: nilgpe@mpei.ru 
changes of the energy potential of forest resources in Russia related to global changes in the carbon cycle and the regional climate changes throughout the country. The immediate goal was to calculate changes in available wood resources suitable for energy use caused by higher primary production of forests due to the increase of carbon dioxide concentration in the atmosphere and changes in air temperature and precipitation. It is necessary to say that the energy potential of Russian forests is immense - each year they produce at least 4 billion tons of organic carbon, or 5 Gtce in terms of conventional fuel, i.e. five times more than the annual energy consumption of the country.

\section{Wood energy resources in Russia}

Forest industry in Russia, like other sectors of the national economy, has undergone radical changes in recent decades (Fig. 1). After doubling of logging in the post-war period (from 150 million $\mathrm{m}^{3}$ in 1945 to 350 million cubic meters in the 1960s) there was a 30 -year period of stable high roundwood removals followed by the sharp decline in the 1990s [6]. Minimum logging was recorded in 1998, at the level of 100 million $\mathrm{m}^{3}$, starting a period of steady growth in the amounts of cutoff, exceeding 200 million $\mathrm{m}^{3}$ in 2017 [1].

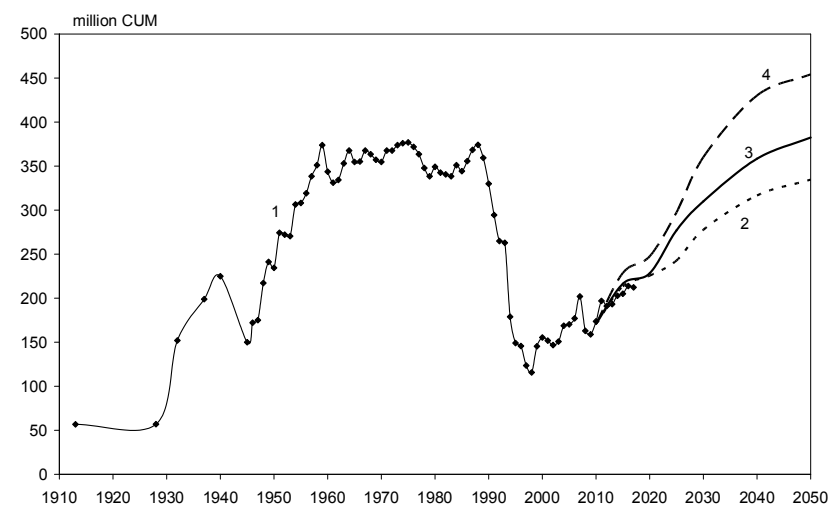

Fig. 1. Forest harvest in Russia: data of Rosstat and [6] for 1910-2017 (1) and scenarios of [7], extrapolated to 2050: inertial (2), moderate (3) and innovative (4)

Data from various sources on the energy use of wood in Russia vary widely [1]. Analysis of official materials of Federal Agency of Forest Resources (Rosleshoz) and Ministry of Energy causes a strong doubt among forest industry experts $[1-2,5]$, arguing that in the last decade about 40 million $\mathrm{m}^{3}$ of wood per year was used as a fuel, of which about a half constituted firewood for the population, and the remainder was wood residuals and waste used in power plants and boilers. According to our estimates, a sound scale of wood energy use was significantly higher and no less than 50-60 million $\mathrm{m}^{3}$.

To assess the potential use of wood resources in the energy sector we used the data on the energy use of wood harvesting and processing waste and residuals, as well as the recycling of wooden products in the largest wood-producing countries (Table 2). The data show that in these countries about $20-30 \%$ of the timber is used as fuel. This share in Russia currently stands at $10 \%$, for a forecast assessment we have used $25 \%$.

Table 2. Share of energy use of industrial roundwood (excluding fuel wood).

\begin{tabular}{|l|l|l|l|l|}
\hline Country & 2000 & 2005 & 2010 & 2015 \\
\hline USA & 0.26 & 0.27 & 0.36 & 0.36 \\
\hline Canada & 0.16 & 0.18 & 0.22 & 0.19 \\
\hline Sweden & 0.19 & 0.10 & 0.28 & 0.25 \\
\hline Finland & 0.20 & 0.24 & 0.34 & 0.24 \\
\hline \multicolumn{5}{|c|}{ Data sources: UN, FAO }
\end{tabular}

For wood harvest projection we used intermediate (moderate) scenario developed jointly by the experts of FAO and Rosleshoz [7], extrapolated to 2050 (Fig. 2). Under this scenario, the potential amount of timber production in Russia by the middle of this century would reach 380 million $\mathrm{m} 3 /$ year that corresponds to the average level of cutoffs for the period 1960-1990. Thus, the energy use of forest resources by 2050 can make 95 million $\mathrm{m} 3$. With a conservative estimate of decentralized firewood production for the households at 20 million m3/year the total amount of wood fuel in Russia can make about 115 million m3/year, or taking into account the calorific value of wood $0.266 \mathrm{tce} / \mathrm{m} 3$, about $30 \mathrm{Mtce} /$ year.

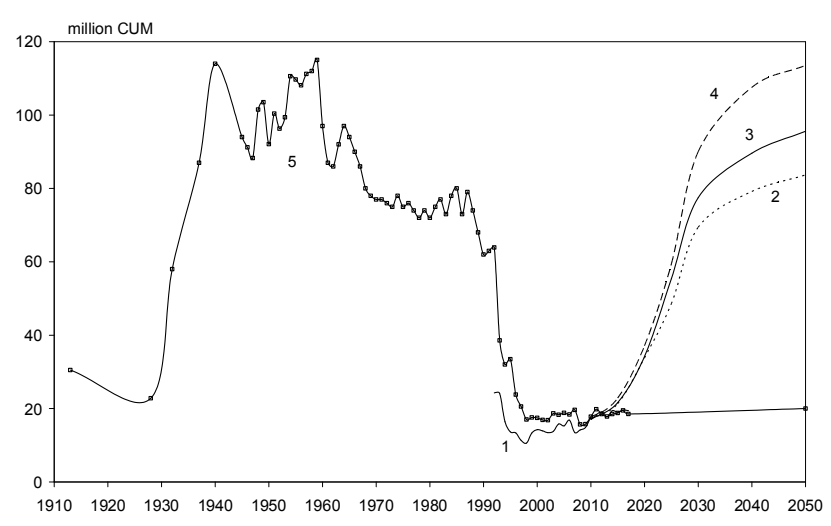

Fig. 2. Commercial energy use of wood in Russia: Rosstat data for 1992-2017 (1) and scenarios of [5], extrapolated to 2050: inertial (2), moderate (3) and innovative (4), and historical fuelwood production (5)

\section{Climate change and $\mathrm{CO}_{2}$ fertilisation impact on forest resources in Russia}

However, these calculations are valid for constant climatic conditions. Our planet is passing through a period of unprecedented on a historical scale changes of carbon dioxide abundance, the main feeding source of plants, and temperature-humidity characteristics that determine the value of primary productivity of forests.

Based on the numerous researches in various natural ecosystems [8] the reliable dependences of forest net primary production (carbon deposits in plants) on climatic parameters were obtained. For the annual ranges of air temperatures from $-5^{\circ} \mathrm{C}$ to $10^{\circ} \mathrm{C}$ and precipitation from 200 to $1000 \mathrm{~mm}$, corresponding to climatic conditions of forest ecosystems in Russia, the Net Primary Production (NPP) is increasing by $0.34 \mathrm{t} / \mathrm{ha}$ with 
air temperature increase by 1 degree and by $0.07 \mathrm{t} / \mathrm{ha}$ with increasing rainfall by $10 \mathrm{~mm} /$ year.

Sensitivity of terrestrial vegetation to changes in the carbon dioxide concentration in the atmosphere is estimated by different models in a very wide range from $12 \%$ to $76 \%$ for doubling of $\mathrm{CO}_{2}$ concentrations and on the average was taken equal to $48 \%$ in the IPCC fourth assessment report twelve years ago [9]. However, the results of many field tests, including long-term natural experiments (i.e., FACE - Free-air $\mathrm{CO}_{2}$ Enrichment [10]) show a much more moderate effect of fertilization, at the average of $20-25 \%$ [11]. In this paper, we used a compromise value of $28 \%$, consistent to what we used in our box-diffusion carbon cycle model with advanced biosphere unit [12], which was applied here for calculations of global changes of the carbon dioxide concentration in the atmosphere. We used as an input the scenarios of anthropogenic influence on the atmosphere [13-14] developed in National Research University "MPEI", taking into account the commitments of the UNFCCC parties on the basis of the Paris Agreement (2015). The results of the global mean atmospheric $\mathrm{CO}_{2}$ concentration calculations for baseline scenario are presented in Fig. 3. The projected increase of the carbon dioxide concentration is estimated from $350 \mathrm{ppm}$ in 1990 to $460 \mathrm{ppm}$ at 2050. Due to $\mathrm{CO}_{2}$-fertilization NPP will increase during this period by approximately $10 \%$.

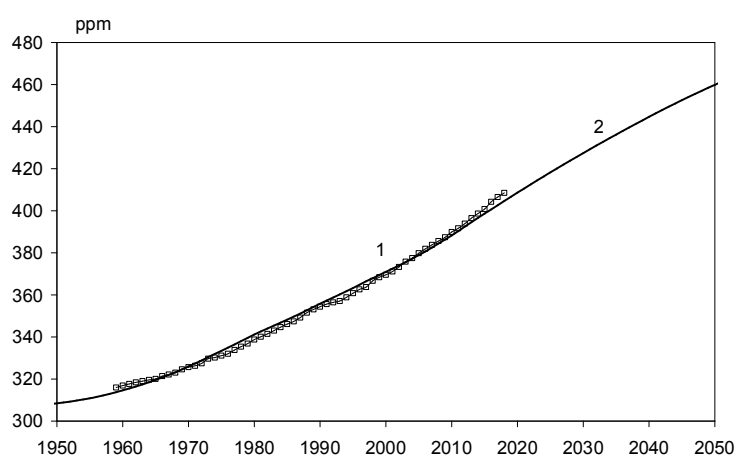

Fig. 3. Global atmospheric $\mathrm{CO}_{2}$ concentrations change: NOAA observation data (1) and model calculations according to base scenario [13] (2)

\section{Results and discussion}

Changes in air temperature over the Russian territory are calculated using a regional climate model [15] combining the principles of dynamic and statistical modeling. Model estimates of mean annual air temperature $\left(\mathrm{T}_{\mathrm{ann}}\right)$ change by the middle of this century on the territory of Russia corresponding to baseline scenario of anthropogenic influence on the atmosphere [13-14] are presented in Fig. 4.

The model simulations show that the more pronounced $\mathrm{T}_{\text {ann }}$ increase (more that $2.5^{\circ} \mathrm{C}$ relative to modern norms of 1971-2010) is anticipated in the southern parts of European and Asian territories with the maximum in Southern Siberia. On the most part of Russian territory the change of $\mathrm{T}_{\mathrm{ann}}$ would be in the limits of $2-2.5^{\circ} \mathrm{C}$ and only northern-western regions would face the moderate warming of less than $2.0^{\circ} \mathrm{C}$.

According to our recent study [16] the precipitation change in Russia in our baseline scenario is estimated as increasing at $5-10 \%$ relative to the modern averages. The model simulations forecast more humid climate in the eastern part of the country and in the North-West of European part (up to $10 \%$ increase in the annual precipitation), less pronounced changes in the central regions (5-10\%) and minor changes (or even some aridification) in the southern regions of European part.

The results of the calculations of the Russian forests NPP change by the middle of this century are summarized in Table 3.

At present the major amount of roundwood (more that $60 \%$ of total) is harvested in the European part of Russia (including Urals), but the main forest resources are located in Siberia and Far East (40\% and 25\% respectively). We assume, that in the nearest decades this disproportion will remain due to transportation problems.

The major changes in NPP due to forthcoming climate change according to our calculations are anticipated in the eastern part of Russia (Urals, Siberia and Far East), where it would increase due to warmer and wetter climate by $25-30 \%$ as compared to the values of the 1990s. The climate-induced NPP increase in the European part of the country is estimated at $15-20 \%$, with the 25\% NPP increase averaged for the whole territory of Russia.

The cumulative effect of climate change and $\mathrm{CO}_{2}$ fertilization is estimated at $25-30 \%$ increase in the European part of Russia and $40-45 \%$ for the Asian part, with the weighted average of $40 \%$. These rather coarse estimates correspond well to other published results.

The authors of [17], basing on the remote sensing data of growing season integrated leaf area index for 1982-2009 and factorial simulations with multiple global ecosystem models, found that climate change has a dominant positive effect on ecosystems productivity in high latitudes $\left(60-90^{\circ} \mathrm{N}\right)$ of Eurasia - three-fold larger than the $\mathrm{CO}_{2}$-fertilization effect. Assuming the latter as $10 \%$, the climate induced NPP increase can be estimated as $30 \%$, that corresponds well to the value of $27 \%$ from Table 3 in the present study.

In [18] a set of simulations to assess the impact of climate change on global forests where MC2 dynamic global vegetation model was run with the MIT Integrated Global System Model-Community Atmosphere Model results under two emissions scenarios: a business-asusual reference scenario analogous to the highest IPCC RCP8.5 scenario, and a greenhouse gas mitigation scenario, called POL3.7, which falls between the IPCC RCP2.6 and RCP4.5 scenarios and is almost adequate to our baseline scenario. The ensemble results of modeling show increase in NPP for Russian forests by $10 \%$ at annual air temperature rise of $2^{\circ} \mathrm{C}$, but comparison of MC2 model output with benchmark dataset for this region over the historic period of 1983-2012 indicates that NPP change was underestimated by $45 \%$, so our estimate of $20 \%$ NPP increase at 2-degrees temperature rise looks realistic. 


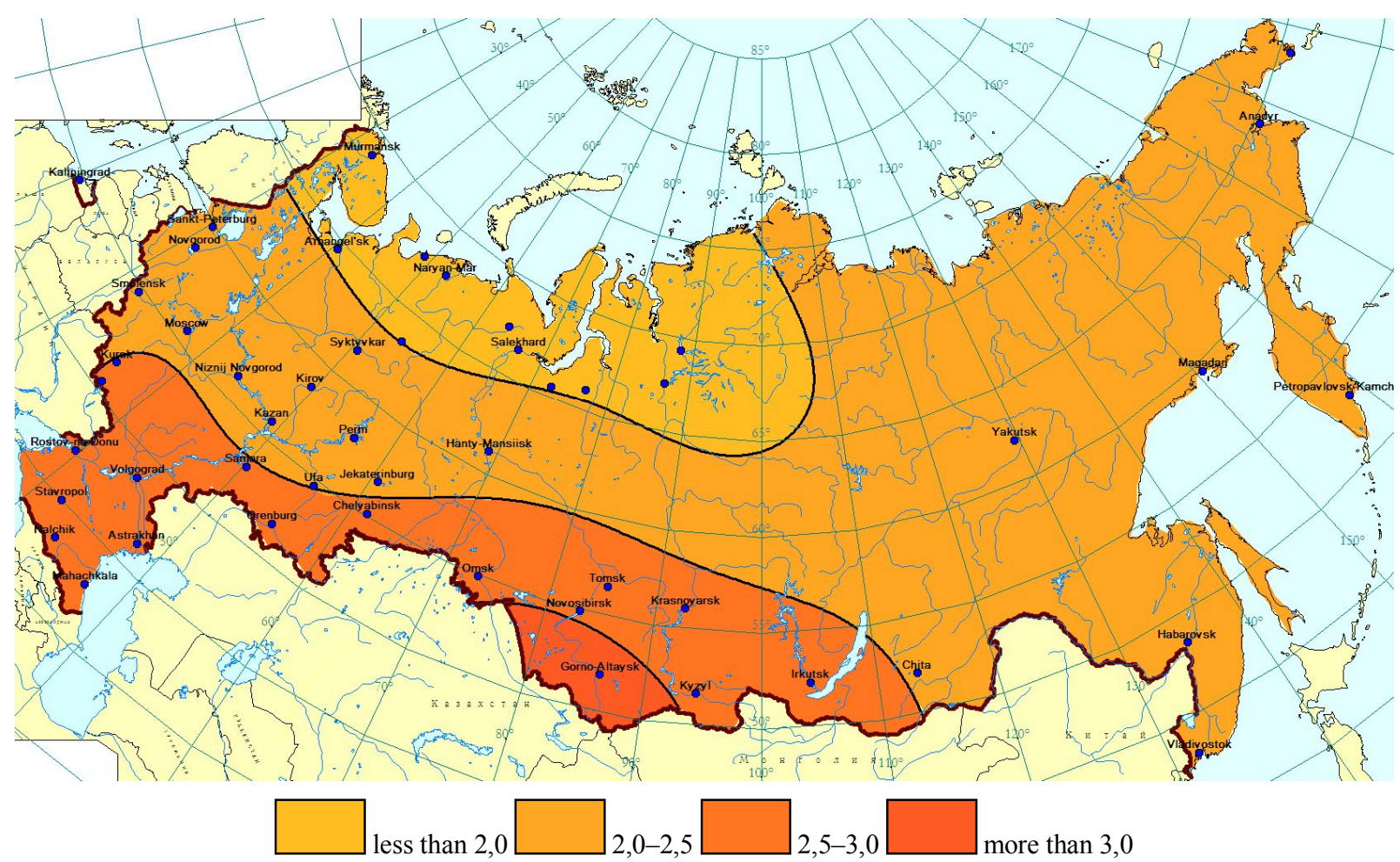

Fig. 4. Mean $T_{a n n}$ change in Russia (relative to 1971-2010 base, degrees Centigrade) to 2050 according to base scenario [13]

Table 3. Share in national roundwood harvest $\delta V$ (decadal average 2008-2017), forest resources $W$ and its specific values $w$, forest area $S$, carbon content $C$ and its specific value $c$, forecasted changes in air temperature $\Delta T$, precipitation $\Delta P$ and net primary production enhancement $\delta N P P$ to 2050 (compared to 1971-2010 base) by federal districts of Russia.

\begin{tabular}{|c|c|c|c|c|c|c|c|c|c|c|c|}
\hline $\begin{array}{l}\text { Federal } \\
\text { district }\end{array}$ & $\delta \mathrm{V}$ & $\begin{array}{l}\text { W, } \\
\text { billion } \\
\text { CUM }\end{array}$ & $\begin{array}{l}\mathrm{S}, \\
\text { million ha }\end{array}$ & $\begin{array}{l}\text { w, } \\
\text { CUM/ha }\end{array}$ & $\begin{array}{l}\text { C, } \\
\text { Gt C }\end{array}$ & $\begin{array}{l}\mathrm{c}, \\
\mathrm{t} \mathrm{C} / \mathrm{ha}\end{array}$ & $\begin{array}{l}\Delta \mathrm{T}, \\
{ }^{\circ} \mathrm{C}\end{array}$ & $\begin{array}{l}\Delta \mathrm{P}, \\
\mathrm{mm}\end{array}$ & $\begin{array}{l}\delta \mathrm{NPP} \\
(\mathrm{T}), \%\end{array}$ & $\begin{array}{l}\delta N P P(P), \\
\%\end{array}$ & $\begin{array}{l}\delta N P P \\
(T, P, \\
C), \%\end{array}$ \\
\hline Central & $10.7 \%$ & 4.0 & 23 & 176 & 2 & 72.2 & 2.5 & 7 & $18 \%$ & $1 \%$ & $31 \%$ \\
\hline North-West & $25.8 \%$ & 10.4 & 89 & 118 & 4 & 48.4 & 1.9 & 9 & $16 \%$ & $1 \%$ & $29 \%$ \\
\hline South & $0.4 \%$ & 0.5 & 3 & 167 & 0 & 68.7 & 2.5 & 4 & $14 \%$ & $1 \%$ & $26 \%$ \\
\hline N. Caucasus & $0.1 \%$ & 0.3 & 2 & 163 & 0 & 67.1 & 2.5 & 2 & $14 \%$ & $0 \%$ & $25 \%$ \\
\hline Volga & $15.9 \%$ & 5.7 & 38 & 151 & 2 & 61.9 & 2.3 & 7 & $19 \%$ & $1 \%$ & $32 \%$ \\
\hline Urals & $8.0 \%$ & 8.1 & 69 & 117 & 3 & 48.0 & 2.3 & 10 & $23 \%$ & $2 \%$ & $37 \%$ \\
\hline Siberia & $31.3 \%$ & 33.2 & 277 & 120 & 14 & 49.2 & 2.7 & 10 & $30 \%$ & $2 \%$ & $45 \%$ \\
\hline Far East & $7.9 \%$ & 20.6 & 295 & 70 & 8 & 28.7 & 2.3 & 11 & $26 \%$ & $2 \%$ & $40 \%$ \\
\hline Russia & $100.0 \%$ & 82.8 & 795 & 104 & 34 & 42.8 & 2.4 & 7.5 & $25 \%$ & $2 \%$ & $40 \%$ \\
\hline
\end{tabular}

Data sources: Rosstat, this study

These calculations should be adjusted for a possible increase in forest loss due to the expected spread of pests and plant diseases, which is estimated to be around $10 \%[2,5]$. Thus, in general, assuming the same areas of wood harvest, the total national wood production is expected to rise in 2050 by some $30 \%$ compared to the recent decades due to an elevated net primary production of forests. Consequently, due to persistent and anticipated climatic changes the available primary energy wood resources by mid-century would increase by more than 9 Mtce that considerably exceeds the climatic impacts on other sectors of energy production - both negative for thermal and nuclear power plants (due to expected reduction of thermal cycle efficiency, which will result in additional fuel consumption of $4.3 \mathrm{Mtce} / \mathrm{year}$ [19]), and positive for hydropower generation (probable growth up to $4 \%$, or 7-8 TWh/year, which is equivalent to the reduction of fossil fuel consumption by 2.5 Mtce/year $[16,19])$.

The estimates of additional timber production in Russia caused by the climate change and $\mathrm{CO}_{2}$ increase are confirmed by the other published studies.

In the paper [20] the long-term effects of potential $\mathrm{CO}_{2}$ fertilization on the global forest sector using the Global Forest Products Model without taking into account the temperature and precipitation effects are assessed. For Europe and Asia the increase in industrial roundwood production due to $\mathrm{CO}_{2}$ atmospheric concentration increase by $100 \mathrm{ppm}$ (using IPCC B2 scenario for the period 2011-2065) was estimated as $6 \%$ and $7.7 \%$ respectively, that is of the same order as the estimate of present study. 
Our estimate of NPP increase of 30\% between 19902050 (taking into account forest losses) is quite consistent to the range of $10-30 \%$ for the observations of 1960-2010 [21].

This paper concerns only natural aspects of future wood energy use. As for technical and economical solutions, recent studies [22-23] stated that the current energy policies need to be examined before biomass is implemented on a larger scale to incorporate proper infrastructure, to assess the governmental support and to encourage partnership between wood industry and power producers.

This study used data obtained from Russian Federal Agency of Statistics (Rosstat, www.gks.ru), Russian Federal Agency of Forest Resources (Rosleshoz, www.rosleshoz.gov.ru), UN Food and Agricultural Organization (FAO, www.faostat.org), International Energy Agency (IEA, www.iea.org), British Petroleum (www.bp.org), National Ocean and Atmospheric Administration (NOAA, www.noaa.gov).

\section{Acknowledgements}

This work was supported by the Ministry of Education and Science of the Russian Federation (project No. 13.1137.2017 with regard to climate change modeling) and the Russian Foundation for Basic Research (grant No. 18-08-00026 with regard to wood energy research).

\section{References}

1. A. B. Levin, V. S. Sukhanov, L. V. Scheremetiev, Forest Bull 437 (2010) (in Russian)

2. F. Kraxner, S. Leduc, S. Fuss, D. G. Schepaschenko, A. Z. Shvidenko, Siberian Forest J 116 (2018) doi: 10.15372/SJFS20180102

3. L. Gustavsson, S. Haus, M. Lundblad, A. Lundström, $\quad$ C. A. Ortiz, R. Sathre, N. Le Truong, P.-E. Wikberg, Renew Sustain $\begin{array}{lllll}\text { Energy } & \text { Rev } & 67 & 612 & \text { (2017) }\end{array}$ doi 10.1016/j.rser.2016.09.056

4. J. Giuntoli, A. Agostini, S. Caserini, E. Lugato, D. Baxter, L. Marelli, Biomass and Bioenergy 89 146 (2016) doi 10.1016/j.biombioe.2016.02.024

5. D. Zamolodchikov, G. Kraev, Sust Forest Manag 4 23 (2016) (in Russian)

6. I. V. Kolesnikov, N. M. Velischanskiy, B. D. Litvinenko, M. M. Lokshin, N. S. Nekrasov, V. M. Akimov, M. D. Girayev, Forest management in Russia 1946-1992 (Research and Information Centre for Forest Resources, Moscow 1996) (in Russian)

7. A. Petrov, M. Lobovikov (eds), The Russian Federation forest sector outlook study to 2030 (FAO, Roma 2012)

8. K. I. Kobak, Biotic components of the carbon cycle (Hydrometeoizdat, Leningrad 1988) (in Russian)

9. W. E. Easterling, P. K. Aggarwal, P. Batima, K. M. Brander, L. Erda, S. M. Howden,
A. Kirilenko, J. Morton, J.-F. Soussana, J. Schmidhuber, F. N. Tubiello, Climate Change 2007: Impacts, Adaptation and Vulnerability 273 (Cambridge University Press, Cambridge, 2007)

10. R. J. Norby, M. G. De Kauwe, T. F. Domingues, R. A. Duursma, D. S. Ellsworth, D. S. Goll, D. M. Lapola, K. A. Luus, A. R. MacKenzie, B. E. Medlyn, R. Pavlick, A. Rammig, B. Smith, R. Thomas, K. Thonicke, A. P. Walker, X. Yang, S. Zaehle, New Phytol 20917 (2016)

11. D. J. Arent, R. S. J. Tol, E. Faust, J. P. Hella, S. Kumar, K. M. Strzepek, F. L. Tóth, D. Yan, Climate Change 2014: Impacts, Adaptation, and Vulnerability. Part A: Global and Sectoral Aspects 659 (Cambridge University Press, Cambridge, UK and New York, NY, USA, 2014)

12. A. V. Klimenko, V. V. Klimenko, M. V. Fyodorov, S. Yu. Snytin Proc. 5th Int Energy Conf 556 (Seoul, Korea 1993)

13. V. V. Klimenko, A. V. Klimenko, O. V. Mikushina, A. G. Tereshin, Doklady Phys 61 301 (2016) doi: 10.1134/S1028335816060070

14. V. V. Klimenko, A. V. Klimenko, A. G. Tereshin, Izvestiya, Atm and Ocean Phys 51138 (2015) doi: 10.1134/S0001433815020073

15. V. V. Klimenko, O. V. Mikushina, A. G. Tereshin Proc. SPIE 10466, 23rd Int Symp on Atmospheric and Ocean Optics: Atmospheric Physics (2017) doi: 10.1117/12.2287753.

16. V. V. Klimenko, E. V. Fedotova, Doklady Phys 64 39 (2019) DOI: 10.1134/S1028335819010051

17. Z. Zhu, S. Piao, R. B. Myneni, M. Huang, Z. Zeng, J. G. Canadell, P. Ciais, S. Sitch, P. Friedlingstein, A. Arneth, C. Cao, L. Cheng, E. Kato, C. Koven, Y. Li, X. Lian, Y. Liu, R. Liu, J. Mao, Y. Pan, S. Peng, J. Peñuelas, B. Poulter, T. A. M. Pugh, B. D. Stocker, N. Viovy, X. Wang, Y. Wang, Z. Xiao, H. Yang, S. Zaehle, N. Zeng, Nat Clim Change $\quad 6 \quad 791$ doi: 10.1038/NCLIMATE3004

18. J. B. Kim, E. Monier, B. Sohngen, G. S. Pitts, R. Drapek, J. McFarland, S. Ohrel, J. Cole, Environ Res Lett 12045001 (2017) doi: 10.1088/17489326/aa63fc

19. V. V. Klimenko, E. V. Fedotova, A. G. Tereshin, $\begin{array}{llll}\text { Energy } & \mathbf{1 4 2} & 1010\end{array}$ doi: 10.1016/j.energy.2017.10.069.

20. J. Buongiorno, For Ecosys 229 (2015) doi : 10.1186/s40663-015-0054-3

21. S. Schaphoff, C. P. O. Reyera, D. Schepaschenko, D. Gertena, A. Shvidenko, For Ecol Manage 361 432 (2016) DOI: 10.1016/j.foreco.2015.11.043

22. N. A. Pambudi, K. Itaoka, A. Chapman, N. D. Hoa, N. Yamakawa, Int J of Smart Grid and Clean Energy 6119 (2017) doi: 0.12720/sgce.6.2.119-126.

23. U. Nzotcha, J. Kenfack, Biomass and Bioenergy 120324

(2019) 